\title{
METODE RASULULLAH DALAM \\ PENGAJARAN SPEAKING
}

\author{
Happy Sri Rezeki Purba
}

\begin{abstract}
Prophet Muhammad SAW is the greatest person that inspired all people in the world by his methods in teaching. The major points of these methods are love and solution that he offered to all of his students.

Particularly in teaching speaking, there are six methods that lecturer can apply in facing the introvert students, they are: (1) exemplary method, (2) systematic method, (3), Discussion Method, (4),Experimental Method, (5) Situational Method, (6) award and punishment method. Through these all methods, it hopes that the introvert student who is close, shy and quiet person can speak freely and active in the class especially in speaking class.
\end{abstract}

\section{Keywords: Methods of Rasulullah, Speaking, Introvert Student}

\section{A. Pendahuluan}

Dalam Alquran surat at-Tin:4, Allah SWT berfirman: "sungguh kami telah menciptakan manusia dalam bentuk yang sangat baik (sempurna)" 1. Allah menciptakan manusia untuk mengabdi kepada Allah SWT dan menjadi kahlifah di muka bumi. Hal ini berarti, manusia berdasarkan fitrahnya adalah mahluk sosial yang bersifat altruis (mementingkan/membantu orang lain). Manusia juga dilengkapi dengan kemampuan bersosialisasi, berinteraksi sosial secara positif dan konstruktif dengan orang lain di lingkungannya.

Sebagai mahluk sosial, manusia memiliki kepribadian yang berbeda satu dengan yang lainnya. Kepribadian dalam Bahasa Arab

${ }^{1}$ Alquran Keluarga, Edisi Hasanah (Bandung: Fitrah Rabbani, 2009), h. 594. 
disebut as-syakhshiyyah berasal dari kata syakhshun, artinya, orang atau seseorang atau pribadi. Kepribadian juga diartikan identitas seseorang yang dibentuk oleh cara berpikirnya dan caranya berbuat untuk memenuhi kebutuhan-kebutuhan atau keinginan-keinginanya ${ }^{2}$.

Kepribadian atau personality berasal dari kata "person" yang secara bahasa memiliki arti (1) an individual human being (sosok manusia sebagai individu), (2) a common individual (individu secara umum), (3) a living human body (orang yang hidup), (4), self (pribadi), (5) personal existence (eksistensi pribadi), (6) distinctive personal character (kekhususan karakter individu) ${ }^{3}$. Secara filosofis dapat juga dikatakan bahwa pibadi adalah "aku yang sejati" dan kepribadian merupakan "penampakan sang aku" dalam bentuk prilaku tertentu. Secara umum kepribadian adalah kesan yang diberikan seseorang kepada orang lain yang diperoleh dari apa yang dipikir, dirasakan, diperbuat yang terungkap melalui perilaku.

Carl Justav Jung 4 merumuskan tipe kepribadian manusia dengan istilah Ekstrovert dan Introvert serta menggambarkan fungsi kepribadian manusia yang disebut fungsi berpikir, pengindera, intuitif, dan perasa.

Ekstrovert adalah kecenderungan yang mengarahkan kepribadian lebih banyak keluar daripada ke dalam diri sendiri. Seorang ekstrover memiliki sifat sosial, lebih banyak berbuat daripada merenung dan berpikir. Sedangkan sikap introvert adalah suatu orientasi ke dalam diri sendiri. Secara singkat seorang introvert adalah orang yang cenderung menarik diri sendiri dari kotntak sosial. Minat dan perhatiannya lebih terfokus pada pikiran dan pengalamannya sendiri. Seorang introvert cenderung merasa mampu dalam upaya

2 Siti Maisyaroh, dalam pengertian kepribadian muslim, http://id.shvoong.com/social-sciences/education /2191444-pengertian-kepribadianmuslim/diakses pada kamis,07 April 2016.pkl 20.00

${ }^{3}$ Arvey, Genetics: Twin and organizational Behavior, Vol. 16 Grreenwich. 2002

4 Ahmad Fauzi, Psikologi Umum (Jakarta: t.p, 2006), h. 116. 
mencukupi dirinya sendiri, sebaliknya orang ekstrover membutuhkan orang lain.

Jung ${ }^{5}$ menguraikan perilaku introvert sebagai orang pendiam, menjauhkan diri dari kejadian-kejadian luar, tidak mau terlibat dengan dunia objektif, tidak senang berada di tengah orang banyak, merasa kesepian dan kehilangan di tengah orang banyak. Ia melakukan sesuatu menurut caranya sendiri, menutup diri terhadap pengaruh dunia luar. Ia orang yang tidak mudah percaya, kadang menderita perasaan rendah diri karena itu ia gampang cemburu dan iri hati. Ia menghadapi dunia luar dengan suatu sistem pertahanan diri yang sistematis dan teliti, tamak sebagai ilmuan, cermat, berhati-hati, menurut kata hati, sopan santun dan penuh curiga.

Berbicara bagi seorang introvert merupakan hal yang sangat serius. Mereka cenderung sangat berhati-hati ketika berbicara dengan orang lain dan tidak dengan sembarangan orang. Ketika kaum introvert harus mempelajari bahasa asing, Bahasa Inggris khususnya ada empat keahlian yang harus dipelajari yaitu listening, reading, writing dan speaking. Menurut beberapa ahli, Speaking atau berbicara adalah ketrampilan seseorang dalam menyampaikan ide atau gagasan melalui bahasa lisan sehingga ide dan gagasan tersebut sampai kepada orang lain.

Dalam mengajarkan Bahasa Inggris kepada kaum introvert tentu bukanlah hal yang mudah dilakukan. Seorang pengajar (dosen) memerlukan metode dan pendekatan yang tepat untuk membuat mereka "percaya" untuk berbicara. M. Sobri Sutikno 6 menyatakan metode pembelajaran adalah cara-cara menyajikan materi pelajaran yang dilakukan oleh pendidik agar terjadi proses pembelajaran pada diri peserta didik dalam upaya untuk mencapai tujuan.

Khususnya dalam pengajaran Speaking tujuan utamanya adalah untuk meningkatkan kemampuan komunikatif peserta didik karena

\footnotetext{
5 Feist, Teori Kepribadian Jilid-2 (Jakarta: Salemba Humanika, 2011), h. 54

6 Sobri Sutikno, Belajar dan Pembelajaran (Bandung: Prospek), h. 88
} 
hanya dengan cara itu, mereka dapat mengekspresikan diri dan belajar bagaimana untuk mengikuti aturan-aturan dan budaya yang tepat dalam setiap berkomunikasi.

Menurut Nunan" "Speaking is a productive aural/oral skill and it consists of producing systemic verbal utterances to convey meaning". Berbicara merupakan kemampuan memproduksi ujaran secara lisan dan sistematis untuk menyatakan suatu kepada orang lain. Dijwandono $^{8}$ menyatakan bahwa "berbicara berarti mengungkapkan pikiran secara lisan".

Element penting dalam berbicara adalah kemampuan mengolah bahasa itu sendiri dan penampilan. Penampilan meliputi 1) Kefasihan (fluency), 2) Ketepatan (accuracy), dan 3) strategi komunikasi (communicative strategies) ${ }^{9}$.

Dalam pencapaian ketiga element di atas, seorang dosen harus menggunakan metode yang jitu dan tepat khususnya bagi mahasiswa introvert yang cenderung pasif dalam komunikasi.

Salah satu metode yang sangat menginspirasi dunia adalah metode Rasulullah SAW. Metode beliau berlandaskan kepada pembentukan karakter dan akhlak peserta didiknya yang seolah-olah terlu-pakan oleh metode modren akhir-akhir ini. Metode Rasulullah SAW terbagi atas: 1) metode dialog dan tanya jawab, 2) metode qishah (cerita), 3) metode tamtsil (perumpamaan), 4) metode targhib (motivasi), 5) metode tarhin (menakut-nakuti, 6) metode qasam (sumpah), 7) metode keteladanan dan lain-lain ${ }^{10}$.

Tulisan ini akan membahas tentang metode metode yang diterapkan Rasululah SAW khususnya terhadap pengajaran berbicara (speaking) mahasiswa introvert.

7 David Nunan, Task Based Language Teaching (New York: Cambridge University Press, 2007) h. 488

8 Djiwandono, Test Bahasa dalam Pengajaran (Bandung: t.p, 2009), h. 118

9 Ibid. h. 119

10 Fatih, Metode Nabi dalam Mendidik dan mengajar (Jakarta Timur: Pustaka Al Azhar, 2007), h.. 65 


\section{B. Identifikasi Masalah}

Berdasarkan latar belakang masalah di atas, maka dapat diidentifikasikan permasalahan sebagai berikut :

1. Mahasiswa introvert cenderung tidak aktif di kelas

2. Kemampuan berbicara (speaking) dalam Bahasa Inggris mahasiswa introvert rendah.

3. Dosen kurang memperhatikan mahasiswa introvert.

4. Metode pengajaran yang kurang tepat dalam mengajarkan berbicara (speaking) bagi mahasiswa introvert.

\section{Tujuan Masalah}

Adapun tujuan masalah ini adalah sebagai berikut:

1. Untuk mengetahui kemampuan berbicara (speaking) mahasiswa introvert dalam Bahasa Inggris.

2. Untuk mengetahui pengaruh metode pengajaran Rasulullah SAW terhadap kemampuan berbicara (speaking) mahasiswa introvert.

\section{Metode Pendidikan dan Pengajaran Rasulullah SAW}

Salah satu faktor penting dalam sistem pendidikan adalah metode pendidikan yang dipergunakan oleh seorang pendidik dalam menyampaikan ilmu pengetahuannya kepada peserta didik. Perlu ditekankan dalam hal ini bahwa tidak ada satu pun metode yang paling tepat untuk diterapkan dalam sebuah proses belajar mengajar karena sebuah metode pendidikan dan pengajaran bergantung pada situasi dan kondisi dari proses belajar mengajar tersebut. Sehingga terkadang seorang pendidik harus menerapkan sebuah metode pendidikan dan pengajaran tertentu pada situasi dan kondisi tertentu dan menggunakan sebuah metode yang lain dalam situasi dan kondisi yang lain pula.

Dalam pengajaran speaking (berbicara) khususnya bagi mahasiswa introvert ada beberapa metode pendidikan dan pengajaran Rasulullah SAW yang dapat diterapkan yaitu: 


\section{Metode Keteladanan}

Sebagai pendidik harus dapat memberikan keteladanan yang baik kepada peserta didiknya. Melirik pada kata-kata berikut "Nabi Muhammad SAW sebagai seorang pribadi adalah contoh terbaik bagaimana Alquran berjalan, bagaimana Alquran hidup dan dihidupkan dalam kehidupan keseharian" diharapkan seorang pendidik atau dosen mencontoh dari kepribadian Beliau sehingga setiap peserta didik memiliki sosok teladan yang baik dan pantas untuk ditiru dan akan menyentuh jiwa peserta didik ${ }^{11}$. Jika metode ini diterapkan oleh dosen dalam mengajar speaking (berbicara) khususnya terhadap mahasiswa introvert tentu mahasiswa tersebut akan "percaya" untuk mulai berbicara dan membuka diri. Sebab mahasiswa yang berkepribadian introvert memerlukan rasa aman dan percaya terlebih dahulu sebelum mereka membuka diri dan berbicara. Sebagai sosok tauladan diharapkan dosen dapat memberi pengaruh positif terhadap mereka ehingga mereka dapat aktif di kelas dan berbicara (speaking) dalam Bahasa Inggris dengan baik.

\section{Metode pentahapan atau pengulangan}

Dalam menyampaikan ilmu pengetahuan kepada peserta didik, Nabi Muhammad SAW tidak serta merta langsung memberikan semua bahan materi yang ada. Namun beliau mentransfer ilmu tersebut melalui sistem pentahapan. Sehingga peserta didik lebih dapat memahami materi yang disampaikan secara maksimal daripada langsung tanpa sebuah pentahapan. Agar materi-materi yang telah diberikan tidak cepat hilang dari ingatan para peserta didik, Nabi Muhammad SAW seringkali mengulang-ulang materi-materi yang sudah beliau sampaikan. Hal tersebut sangat berguna untuk membantu agar tetap dapat mengingat dan mengulang kembali apaapa yang telah diajarkan oleh Nabi Muhammad SAW 12. Dalam

\footnotetext{
11 Ibid.h. .67

12 Ibid., h. 70
} 
pengajaran Speaking atau berbicara dalam Bahasa Inggris, tentu seorang dosen harus dapat memberikan materi secara bertahap mulai dari greeting (sapaan), Introduction (perkenalan), hingga ekspresiekspresi yang digunakan dalam berbagai kondisi dan situasi.

Seorang dosen harus mampu membuat pentahapan secara sistematis dan bertahap mulai dari hal yang termudah hingga tersulit hal ini tentu akan memudahkan peserta didik untuk dapat memahami materi. Bagi mahasiswa introvert yang cenderung pasif di kelas, proses pentahapan dan pengulangan ini sangat bermanfaat. Sebab dosen memberikan waktu lebih bagi mereka untuk "peduli" terhadap proses belajar mengajar yang sedang berlangsung. Mereka akan peduli dengan hal yang dilakukan dengan pentahapan begini daripada pembelajaran yang langsung ke inti karena bersifat instan dan cepat.

\section{Metode tanya jawab dan diskusi}

Metode ini diterapkan oleh Nabi Muhammad SAW dalam rangka memberikan kesan perhatian kepada peserta didik, memberikan motivasi, dan mengetahui potensi akal peserta didik untuk dapat menjelaskan lagi apa yang telah peserta didik ketahui. Dan metode ini dapat dijadikan sebagai tolak ukur akan pemahaman yang dikuasai peserta didik terhadap materi-materi yang telah diberikan oleh Rasulullah. Nabi Muhammad SAW selalu membuka lebar atas pengajuan pertanyaan dari peserta didik beliau secara proporsional atas pertanyaan-pertanyaan yang peserta didik ajukan. Metode tanya jawab berusaha menghubungkan pemikiran seseorang dengan orang lain, serta mempunyai mamfaat bagi pelaku dan pendengarnya melalui dialog, perasaan dan emosi pembaca akan terbangkitkan, jika topik pembicaraan disajikan bersifat realistik dan manusiawi ${ }^{13}$. Terdapat banyak sekali dialog atau pun percakapan dalam bahasa Inggris yang tentunya menjadi materi pokok dosen dalam pengajaran berbicara (speaking). Metode tanya jawab ini merupakan salah satu bentuk

${ }^{13}$ Ibid., h. 74 
praktek mahasiswa sebagai tolak ukur dosen apakah mahasiswa telah mampu bertanya dan memberikan pendapat atau jawaban dengan mempergunakan bahasa Inggris. salah satu kendala yang dihadapi oleh dosen adalah mahasiswa yang "malas" untuk bertanya dan terutama hal ini terjadi pada mahasiswa introvert.

Mahasiswa yang pendiam ataupun introvert sesungguhnya memiliki perhatiannya yang cukup terhadap lingkungan sekitar ataupun orang lain, hanya saja mereka lebih senang untuk berpikir dan menyimpannya sendiri. Metode tanya jawab yang diterapkan rasul merupakan metode yang setiap peserta didik akan tertarik untuk bertanya sebab Rasulullah selalu mengkaitkannya dengan realitik dan personal.

Bagi mahasiswa introvert yang dominan lebih banyak berpikir dari pada berbicara ini akan terangsang untuk mendiskusikan pemikiran mereka dengan dosen sebab mereka diberi kesempatan untuk didengar dan diberi tanggapan secara proporsional dan bahkan melibatkan peserta didik yang lain. Dan tentu saja dengan diskusi serta tanya-jawab ini kemampuan berbicara peserta didik akan meningkat karena mereka diberi kesempatan untuk mengaplikasikan atau mempraktekkan kemampuan berbicara yang meliputi penguasaan vocabulary, pronunciationm, grammar dan fluency (kefasihan).

\section{Metode Alat Peraga dan Eksperimen}

Metode pengajaran Rasulullah ini adalah dengan cara mendemonstrasikan sesuatu oleh beliau ketika hendak mengajarkan sesuatu. Dalam metode ini cara yang beliau terapkan adalah dengan menunjukkan sesuatu yang menjadi objek pembahasan kehadapan peserta didik beliau. Dengan metode ini, dapat menarik perhatian peserta didik untuk lebih tergugah dalam memperhatikan apa yang sedang beliau ajarkan. Metode ini juga dapat lebih mempermudah 
peserta didik untuk memahami materi-materi yang sedang diajarkan beliau.

Metode demonstrasi dimaksudkan sebagai suatu kegiatan memperlilhatkan suatu gerakan atau proses kerja sesuatu. Pekerjaannya dapat saja dilakukan oleh pendidik atau peserta didik yang diminta mempraktekkan sesuatu pekerjaan. Metode demostrasi bertujuan agar pesan yang disampaikan dapat dikerjakan dengan baik dan benar ${ }^{14}$.

Metode demonstrasi dapat dipergunakan dalam organisasi pelajaran yang bertujuan memudahkan informasi dari model hidup, simbolik, deksripsi verbal. Demontrasi yang dapat digunakan dalam pengajaran speaking adalah dengan mempergunakan media TV ataupun Video. Khususnya dalam pengajaran Bahasa Inggris tentu ada banyak film, video ataupun rekaman percakapan singkat yang dapat mendukung proses belajar mengajar. Dengan metode demonstrasi atau pun eksperimen ini mahasiswa akan lebih tertarik khususnya bagi mahasiswa introvert.

Nabi Muhammad SAW mengajarkan kepada peserta didik beliau tentang suatu kaedah yang besar yaitu tentang ilmu pengetahuan, dan menanamkan metode umum dalam penelitian ilmiah dalam ilmu pengetahuan. Hal tersebut merupakan hasil perubahan dan pengalaman, pengamatan dan penelitian. Oleh karena itu diperlukan metode eksperimen untuk mendapatkan hakekat ilmu pengetahuan. Untuk menguatkan kaedah ini dan mengajarkannya serta agar senantiasa terekam kuat dalam ingatan peserta didik, Nabi Muhammad SAW membimbing peserta didik beliau untuk melakukan suatu percobaan dan pengamatan, bukan hanya sekedar menyampaikan teori.

\section{Metode situasional dan kondisional}

14 Ibid., h. 77 
Ketika memberikan pengajaran kepada peserta didik, Rasullulah senantiasa memperhatikan waktu dan kondisi yang tepat bagi peserta didik beliau. Hal ini bermamfaat agar peserta didik tidak merasakan sebuah rasa kejenuhan. Bila timbul rasa kejenuhan maka kelangsungan proses belajar mengajar menjadi tidak maksimal bahkan menjadi sia-sia. Oleh karena itu, perlu diantisipasi akan munculnya rasa kejenuhan tersebut.

Dalam sudut pandang keseragaman kemampuan peserta didik dalam memahami suatu transfer ilmu pengetahuan, Nabi Muhammad SAW sangat memperhatikan kondisi kompetensi yang dimiliki oleh masing-masing peserta didik dalam setiap aktivitas pengajaran. Beliau senantiasa memberikan pengajaran kepada peserta didik beliau sesuai dengan kadar pemahaman peserta didik. Beliau tidak mengajarkan kepada peserta didik pemula sesuatu yang hal yang beliau ajarkan kepada peserta didik senior. Beliau juga tidak mengucilkan peserta didik yang junior terhadap peserta didik yang sudah senior.

Hal ini erat sekali kaitannya dengan mahasiswa introvert juga terkesan "junior" jika dibandingkan dengan mahasiswa ekstrovert. Melalui menerapkan metode situational dan kondisional ini maka pendidik (dosen) dapat lebih bijaksana dalam mentransfer ilmu pengetahuan khususnya dalam kelas Speaking (berbicara) dalam bahasa Inggris. Seorang dosen harus memperhatikan kondisi kompetensi peserta didiknya dan senantiasa memberikan pengajaran sesuai dengan kadar pemahaman peserta didik. Khususnya bagi mahasiswa introvert tentu diperlukan pengajaran yang sesuai dengan kadar kemampuan mereka dan memberikan lebih banyak kesempatan dalam praktek berbicara (speaking). Dengan menerapkan metode ini diharapkan mereka tidak lagi merasa "junior" sebab diberikan pengajaran yang sesuai dengan apa yang mereka pahami dan butuhkan.

\section{Metode membangkitkan perhatian, pujian dan hukuman.}


Dalam membangkitkan perhatian peserta didik, Rasulullah menggunakan beberapa cara yaitu: dengan cara mengulangi penjelasan dan menunda jawaban, memanggil peserta didik, memegang tangan atau bahu peserta didik dan merubah posisi. Hal ini dimaksudkan agar perhatian peserta didik menjadi bertambah, serta demi mengarahkan pendengaran, penglihatan, dan hati peserta didik agar secara fisik dan psikologis lebih siap dan lebih memperhatikan apa yang beliau ajarkan.

Ketika didapati ada peserta didik beliau yang menampilkan sikap atau perbuatan yang tak semestinya ia lakukan maka dengan segera Rasulullah akan memperingatkannya. Namun bila sikap dan perbuatan tersebut sudah terlampau batas kewajaran maka Beliau pun mulai menampakkan kemarahannya. Tentu kemarahan tersebut tetap dengan maksud mendidik dan bukanlah luapan emosi yang berlebihan.

Rasulullah senantiasa memanfaatkan kesempatan (momentum) yang sesuai atas hal yang hendak beliau ajarkan. Beliau berusaha memadukan antara kesesuaian momentum dan ilmu pengetahuan yang hendak diajarkan secara kondusif, dengan harapan agar lebih jelas dalam memberikan sebuah kepahaman keilmuan.

Rasulullah juga selalu memotivasi peserta didiknya dengan berdalil kepada Alquran dan Al-Hadist, bahwa setiap insan yang mencari ilmu (belajar) akan mendapatkan balasan yang berlipat-lipat dari Allah SWT dan mendapatkan kedudukan yang mulia. Tentu hal ini, menjadi motivasi bagi peserta didik untuk senantiasa giat dalam menuntut ilmu ${ }^{15}$.

Seseorang dengan kepribadian introvert sesungguhnya juga memerlukan perhatian, pujian atau pun bahkan hukuman untuk menunjukkan bahwa seorang pendidik peduli terhadap mereka dan tidak mengkesampingkan kehadiran mereka yang pendiam atau bahkan pemalu. Sebab sesungguhnya mereka juga memiliki potensi yang sama bahkan lebih besar dengan orang lain. Untuk itu diperlukan

${ }^{15}$ Ibid., h. 79 
pula motivasi yang sesuai berupa keberhasilan-keberhasilan yang akan mereka dapatkan jika dapat berbicara (speaking) dalam Bahasa Inggris dengan baik seperti mendapatkan pekerjaan yang baik, sampai beasiswa ataupun kesempatan dalam bidang international.

Banyak sekali tokoh-tokoh dunia yang berkepribadian introvert seperti JK. Rowling, Bill Gates, Abraham Lincoln dll yang dapat juga disampaikan oleh pendidik untuk tetap mengeinspirasi mereka dan menumbuhkan kepercayaan diri mereka untuk berbicara (speaking) khususnya dalam Bahasa Inggris.

\section{E. Kesimpulan}

Kepribadian atau watak, ciri khas atau karakter seseorang dapat mempengaruhi seluruh aspek kehidupannya begitu pula ketika ia mengeyam pendidikan di perguruan tinggi. Mahasiswa yang berkepribadian introvert cenderung tidak banyak bicara, pemalu dan menutup diri dari dunia luar maupun orang lain. Bahasa Inggris sebagai bahasa international merupakan mata kuliah wajib yang harus dipelajari oleh mahasiswa introvert khusunya yang berkaitan dengan berbicara (speaking).

Dalam kemampuan berbicara ada beberapa element penting yang harus dikuasai yaitu: vocabulary (kosa kata), pronunciation (pelafalan kata), fluency (kefasihan) dan grammar (tata bahasa). Oleh sebab itu diperlukan metode yang teapt yang dapat memastikan bahwa element tersebut dikuasai oleh peserta didik khususnya mahasiswa introvert. Rasulullah sebagai seorang inspirator menerapkan metode-metode pengajaran yang dapat pula diterapkan dalam pengajaran speaking yaitu; (1) Metode ketauladanan, (2) Metode pentahapan, (3) Metode tanya jawab dan diskusi, (4) Metode alat peraga dan eksperimen, (5) Metode situasional dan kondisional, (6) Metode membangkitkan perhatian, pujian dan hukuman.

Setiap metode yang diterapkan Rasulullah di atas memberikan inspirasi bagi peserta didik untuk turut pula membentuk karakter 
peserta didik sesuai dengan yang diharapkan dan tentu dimulai dengan pembentukan karakter oleh pendidik terlebih dahulu. Sebab "khoirunnas Anfa "uhum linnas" sebaik-baiknya manusia adalah yang bermanfaat bagi manusia lainnya. (HR. Bukhari Muslim).

\section{F. Saran-saran}

Adapun saran-saran dari tulisan ini adalah:

1. Seorang pendidik (dosen) dapat menerapkan ke enam metode pengajaran Rasulullah tersebut dalam pengajaran berbicara (speaking) dalam Bahasa Inggris.

2. Mahasiswa introvert agar juga turut berpartisipasi dalam proses pembelajaran dan mau membuka diri sebab speaking (berbicara) merupakan salah satu keahlian yang sangat bermanfaat dalam menghadapi persaingan kerja nantinya setelah menyelesaikan pendidikan di perguruan tinggi.

3. Universitas maupun instansi terkait untuk dapat mendukung proses pembelajaran dengan metode Rasulullah sebab metode Beliau tidak hanya menciptakan manusia-manusia yang memiliki berintelektual tinggi namun juga berkepribadian dan akhlak yang baik pula.

\section{DAFTAR PUSTAKA}

Alquran Keluarga Edisi Hasanah, Bandung: Fitrah Rabbani, 2009

Arvey, Genetics, Twin and organizational Behavior,vol 16 Grreenwich, 2002

Djiwandono, Test Bahasa dalam Pengajaran, Bandung, 2009.

Fatih,Muhammad, Metode Nabi dalam Mendidik dan Mengajar, Jakarta Timur: Pustaka Al Azhar, 2007.

Fauzi Ahmad, Psikologi Umum, Jakarta, 2006.

Feist, Teori Kepribadian Jilid2, Jakarta: Salemba Humanika, 2011 
Sobri Sutikno, Belajar dan Pembelajaran, Prospek Bandung

Nunan, David Task Based Language Teaching, New York. Cambridge University Press.

http:/ /id.shvoong.com/social-sciences/education /2191444-

pengertian-kepribadian-muslim/ diakses pada kamis,07 April 2016.pkl 20.00

http://meyori30.wordpress.com/2008/07/26/akhlak-nabi-

muhammad-saw/ diakses pada Senin, 16 mei 2016 pukul 16.00 